\title{
Przyszłość pracowniczego podporządkowania jako cechy konstrukcyjnej stosunku pracy
}

\section{Uzasadnienie kryterium pracowniczego podporządkowania w stosunku pracy}

Y ryterium pracowniczego podporządkowania, którego istotą jest pod亿danie się pracownika kierownictwu pracodawcy w procesie wykonywania pracy, w doktrynie i judykaturze od samego początku prawa pracy stanowiło nieodłączny (konieczny) element stosunku pracy (najbardziej podstawową konstrukcyjną cechę tego stosunku), odróżniający go od pozostałych form zatrudnienia, zwłaszcza tych o charakterze cywilnoprawnym $^{1}$. Wynika to z przyjętego na przełomie XVIII i XIX w. modelu najmu siły roboczej za wynagrodzeniem, w ramach którego praca ludzka stała się przedmiotem umowy. Nie mógł być to jednak typowy wynajem, gdyż najemca (podmiot zatrudniający) nie miał możliwości w tym przypadku przejęcia na własność „pracy” (przedmiotu umowy). Podporządkowanie pracownika woli pracodawcy miało zatem w założeniu rekompensować niemożność bezpośredniego wejścia pomiotu zatrudniającego w posiadanie siły roboczej, do której pracodawca nabył prawo w drodze umowy. Zdaniem M. Fabre-Magnana, „stanowiąc wyjątek od tego, co zwykle przyjmuje się za istotę wynajmu, nie ma w tym przypadku materialnego przekazania siły roboczej na rzecz pracodawcy, jako że nie istnieje możliwość oddzielenia jej od ciała pracownika. [...] Podporządkowanie wydaje się w tym przypadku być substytutem wywłaszczenia" ${ }^{2}$.

* Dr hab., Katedra Prawa Pracy, Wydział Prawa i Administracji Uniwersytetu Łódzkiego.

1 Zob. literaturę i orzecznictwo sądowe potwierdzające tę tezę w: T. Duraj, Tradycyjne ujęcie pracowniczego podporzadkowania - wybrane problemy prawne, "Studia Prawno-Ekonomiczne" 2011, t. LXXXIII, s. 35 i n.

${ }^{2}$ M. Fabre-Magnan, Le contrat de travail défini par son objet, [w:] Le travail en perspectives, Paris 1998, s. 101 i 119. 
Jak słusznie podsumował to A. Supiot, „,w umowie o pracę połączono tym sposobem pracę, stanowiącą dobro, które można od pracownika odseparować, podporządkowaniem, stanowiącym szczególną formę wejścia w posiadanie tego dobra"3.

Model zatrudnienia pracowniczego wymaga, moim zdaniem, podporządkowania pracowników w procesie pracy woli kierownictwa podmiotu zatrudniającego. Skoro pracodawca został zobligowany, pod sankcją kary, do zapewnienia prawidłowej organizacji pracy oraz przygotowania procesu produkcyjnego w sposób gwarantujący pracownikom bezpieczne i higieniczne warunki pracy, to oczywistą konsekwencją tego musi być ich podporządkowanie podmiotowi zatrudniającemu. Pracodawca winien mieć zagwarantowane prawem określone uprawnienia kierownicze, które pozwolą mu na właściwe zorganizowanie środowiska i toku pracy. To wreszcie pracodawca ponosi ryzyko związane z zatrudnianiem pracowników i realizacją procesu pracy. Dzięki przysługującym mu kompetencjom dyrektywnym może efektywnie spożytkować posiadany potencjał pracy, łagodząc ryzyko niedostępności czy nieprzydatności świadczenia.

Konieczność zagwarantowania pracodawcy w ramach stosunku pracy wpływu na zachowania pracowników, za których on odpowiada, dobrze uzasadnił już w latach siedemdziesiątych poprzedniego stulecia H. Lewandowski. Według niego uprawnienia kierownicze pracodawcy, których konsekwencję stanowi pracownicze podporządkowanie, wywodzą się przede wszystkim z niemożności określenia szczegółowo - przy nawiązaniu stosunku pracy - zobowiązania pracownika, które w umowie i przepisach z natury rzeczy ustalane jest dość ogólnie. Podmiot zatrudniający musi mieć zatem możliwość konkretyzacji tego zobowiązania i temu właśnie służą zagwarantowane mu przepisami prawa pracy uprawnienia kierownicze ${ }^{4}$. Ten rodzaj uprawnień - zdaniem H. Lewandowskiego - „stanowi więc szczególną właściwość stosunku pracy, bez której nie mógłby on być tak zakwalifikowany"

3 A. Supiot, Zatrudnienie pracownicze i zatrudnienie niezależne, [w:] Referaty na VI Europejski Kongres Prawa Pracy i Zabezpieczenia Społecznego, Warszawa 1999, s. 138.

${ }^{4}$ Zob.: H. Lewandowski, Uprawnienia kierownicze w umownym stosunku pracy, Warszawa 1977, s. 21; idem, Możliwość kontrolowania pracownika w ramach uprawnień kierowniczych pracodawcy - zagadnienia ogólne, [w:] Kontrola pracownika. Możliwości techniczne i dylematy prawne, red. Z. Góral, Warszawa 2010, s. 29. Por. też J. Stelina w: Zarys systemu prawa pracy. Część ogólna prawa pracy, t. I, red. K.W. Baran, Warszawa 2010, s. 104.

${ }^{5}$ H. Lewandowski, Uprawnienia kierownicze..., s. 21. 


\section{Pracownicze podporządkowanie jako cecha konstrukcyjna stosunku pracy - uwagi de lege lata}

Analizując pracownicze podporządkowanie de lege lata należy przyjąć, że jest to stosunek zależności występujący pomiędzy podmiotem wykonawczym (pracownikiem) a podmiotem decyzyjnym (pracodawca), w ramach którego pracodawca może, za pomocą uprawnień kierowniczych konkretyzujących (w drodze wiążących poleceń) obowiązki pracownicze, oddziaływać na zachowanie pracownika w procesie pracy. Przedmiotem tego oddziaływania może być rodzaj świadczonej pracy (przydzielenie pracownikowi zadań do wykonania, wybór metod i środków ich wykonania oraz ewentualne doprecyzowanie sposobu ich realizacji), miejsce i czas pracy (doprecyzowanie miejsca i czasu wykonywania zadań powierzonych pracownikowi) oraz wewnętrzny porządek w zakładzie. Podporządkowanie to także podległość obowiązującej u danego pracodawcy organizacji, w tym również organizacji czasu pracy. Oczywiście przedstawiona tu formuła pracowniczego podporządkowania nie zawsze jest w pełni obecna w każdym zatrudnieniu pracowniczym. Nie wszystkie elementy tak rozumianego podporządkowania muszą występować jednocześnie i z jednakową intensywnością. Według mnie, warunkiem sine qua non istnienia pracowniczego podporządkowania w każdym stosunku pracy, absolutnym minimum potrzebnym do identyfikacji stosunku pracy, jest posiadanie przez pracodawcę (którego reprezentuje przełożony) uprawnienia w przedmiocie konkretyzacji - w drodze wiążących poleceń - obowiązków pracowniczych.

Pomimo nieodwracalnych zmian warunków społeczno-gospodarczych, postępującego rozwoju technologicznego, upowszechniania się nowoczesnych odmian organizacji pracy oraz nietypowych (elastycznych) form zatrudnienia pracowniczego (takich, jak choćby telepraca), które akcentują większą autonomię i niezależność pracownika, podporządkowanie nadal stanowi podstawową, konieczną i najważniejszą (konstrukcyjną) cechę, która decyduje o istnieniu stosunku pracy, wyznaczając zakres jego wykorzystania, a przez to przesądza o zakresie zastosowania prawa pracy. Tezę tę potwierdzają zarówno akty prawa międzynarodowego ${ }^{6}$ oraz dorobek orzeczniczy Trybunału Sprawiedliwości Unii Europejskiej”,

${ }^{6}$ W szczególności należy tu zwrócić uwagę na przyjęte dnia 15 czerwca 2006 r. Zalecenie nr 198 MOP dotyczące stosunku pracy, które bezpośrednio odwołuje się do pracowniczego podporządkowania jako cechy konstrukcyjnej stosunku pracy (zob. ust. 12 i 13).

7 Zob. np.: Sprawa C-66/85 Deborah Lawrie-Blum v. Land Baden-Württemberg, [1986] ECR 2121; Sprawa C-107/94 Asscher v. Staatssecretaris van Financiën, Zb. Orz. 1996, s. I-3089, pkt 26; Sprawa C-337/97 C.P.M. Meeusen v. Hoofddirectie van de InformatieBeheerGroep, [1999] ECR I-3298, pkt 13-15; Sprawa C-268/99 Aldona Małgorzata Jany and Others v. Staatssecretaris 
jak i wykładnia historyczna, literalna, systemowa, a także aksjologiczna polskich przepisów prawa pracy. Poza nielicznymi wyjątkami, powyższy pogląd jest powszechnie akceptowany zarówno w literaturze przedmiotu (przez doktrynę okresu międzywojennego i współczesnych badaczy prawa pracy), jak i w orzecznictwie sądowym, konsekwentnym w tej kwestii od początku prawa pracy. Potwierdza to również analiza porządków prawnych obowiązujących w innych krajach, zwłaszcza europejskich, gdzie pracownicze podporządkowanie uważane jest za kluczowy i najistotniejszy element stosunku pracy ${ }^{8}$.

Biorąc pod uwagę doniosłość pracowniczego podporządkowania, które jako konstytutywna cecha stosunku pracy decyduje o jego odróżnieniu od innych prawnych form zatrudnienia, zwłaszcza tych o charakterze cywilnoprawnym (o tożsamości stosunku pracy), krytycznie należy ocenić obowiązujący $\mathrm{w}$ tym zakresie stan przepisów naszego prawa pracy. Nie dość, że ustawodawca nie posługuje się w ogóle tym terminem, to jeszcze nie wyjaśnia użytego $\mathrm{w}$ art. $22 \S 1$ Kodeksu pracy ${ }^{9}$ pojęcia „pod kierownictwem pracodawcy”. Taki stan prawny prowadzi do wielu sporów i dyskusji w doktrynie prawa pracy, jak i judykaturze oraz w praktyce nad treścią wskazanych pojęć. W literaturze przedmiotu prezentowane są bardzo różne ujęcia definicyjne zarówno w odniesieniu do pracowniczego podporządkowania, jak i kierownictwa pracodawcy (od bardzo szerokiego do nadmiernie wąskiego). Nie ma również pełnej zgodności co do wzajemnej relacji pomiędzy tymi terminami. Poglądy wygłaszane w tej materii są sprzeczne, a niekiedy wręcz wykluczają się. Analiza elementów składających się na treść pracowniczego podporządkowania w kwestii przedmiotu świadczenia pracy (rodzaju pracy i sposobu jej wykonywania), miejsca i czasu pracy oraz porządku i organizacji pracy, pokazuje, że jest ono - według mnie - pojęciem szerszym niż użyty przez ustawodawcę termin ",kierownictwo pracodawcy”. Widoczne jest to zwłaszcza w obszarze organizacji i porządku, w tym także organizacji czasu pracy obowiązującej $\mathrm{w}$ danym zakładzie pracy. Tutaj bowiem podporządkowanie pracownika znacznie wykracza poza zakres uprawnień kierowniczych pracodawcy. Wynika to z faktu, że organizacja i porządek $\mathrm{w}$ procesie pracy oraz związane $\mathrm{z}$ tym prawa i obowiązki stron stosunku pracy, a także organizacja czasu pracy (obowiązujące $u$ danego pracodaw-

van Justitie, [2001] ECR I-8615. Por. też: Sprawa C-228/07 Petersen (nie publikowany) z 11.9.2008 r., pkt 45; Sprawa Athanasios Vatsouras (C-22/08), Josif Koupatantze (C-23/08) v. Arbeitsgemeinschaft (ARGE) Nürnberg 900 z 4.6.2009 r. [w:] E. Skibińska, Prawo poszukujacych pracy do pobierania świadczeń, „Monitor Prawa Pracy” 2009, nr 8, s. 447-448.

8 Zob. T. Duraj, Podporządkowanie pracowników zajmujących stanowiska kierownicze w organizacjach, Warszawa 2013, s. 21-80.

${ }^{9}$ Ustawa z dnia 26.6.1974 r. - Kodeks pracy, t.j., DzU z 2014 r., poz. 1502. 
cy systemy i rozkłady czasu pracy) najczęściej ustalane są w regulaminie pracy lub układzie zbiorowym pracy, a zatem przy ograniczonym wpływie pracodawcy, który musi tu z reguły współpracować z działającymi $\mathrm{u}$ niego organizacjami związkowymi. Nawet jednak, kiedy kompetencję w przedmiocie uchwalenia regulaminu zachowuje wyłącznie pracodawca (np. gdy nie działają u niego organizacje związkowe), wydany przez niego regulamin pracy nadal jest aktem normatywnym stanowiącym źródło prawa na terenie całego zakładu pracy, wobec wszystkich zatrudnionych w nim pracowników, nie zaś uprawnieniem kierowniczym pracodawcy. Regulamin pracy jest jedynie instrumentem realizacji pracowniczego podporządkowania.

Niezależnie do różnych interpretacji pracowniczego podporządkowania pojawiających się $\mathrm{w}$ literaturze przedmiotu, krytycznie należy ocenić brak ustawowej regulacji minimalnego zakresu tego kryterium, który pozwoliłby na stwierdzenie istnienia stosunku pracy $\mathrm{w}$ odniesieniu do każdego wykonawcy pracy. Chodzi o ustalenie uniwersalnego „rdzenia", którego występowanie w danym stosunku zatrudnienia wskazywałoby na pracowniczy charakter zatrudnienia, a którego brak stanowiłby wystarczająca podstawę do zakwestionowania istnienia stosunku pracy. Wskazany tu "trzon" pracowniczego podporządkowania powinien być tak określony przez ustawodawcę, aby z jednej strony pozwalał na identyfikację tego stosunku i odróżnienie go od cywilnoprawnych form zatrudnienia, a z drugiej nie wykluczał autonomii pracowników samodzielnych i wysokospecjalistycznych oraz nie przekreślał rozwoju elastycznych form zatrudnienia pracowniczego. Analiza przepisów prawa pracy oraz dorobku doktryny i orzecznictwa sądowego skłania do konstatacji, iż minimalnym przejawem podporządkowania w każdym stosunku pracy, spełniającym powyższe kryteria, jest uprawnienie pracodawcy (w imieniu którego działa przełożony) do konkretyzowania - w drodze wiążących poleceń - obowiązków pracowniczych. Podmiot zatrudniający może nie korzystać z tego uprawnienia, gwarantując pracownikowi daleko idącą autonomię i niezależność, ale kompetencja ta cały czas musi mu przysługiwać na gruncie stosunku pracy. Ponadto polecenia, o których tu mowa, nie muszą zawsze dotykać istoty świadczonej pracy (sposobu jej wykonywania). Mogą one bowiem konkretyzować jedynie niektóre, często drugorzędne, obowiązki pracownika odnoszące się do techniczno-organizacyjnej strony świadczenia pracy. Zresztą wskazana tu formuła minimalnego zakresu podporządkowania de lege lata ma swoje podstawy (choć nie zostało to dostatecznie wyraźnie sprecyzowane) również w obowiązujących przepisach prawa pracy. Wynika ona pośrednio zarówno z art. $22 \S 1$ k.p., w ramach którego „pracownik zobowiązuje się do wykonywania pracy określonego rodzaju na rzecz pracodawcy i pod jego kierownictwem oraz 
w miejscu i czasie wyznaczonym przez pracodawcę", jak i z art. $100 \S 1$ k.p., który stanowi, że „pracownik jest obowiązany wykonywać pracę sumiennie i starannie oraz stosować się do poleceń przełożonych, które dotyczą pracy, jeżeli nie są one sprzeczne z przepisami prawa lub umową o pracę". Tak określony "trzon” podporządkowania, którego konieczny element stanowi uprawnienie pracodawcy do konkretyzowania - $\mathrm{w}$ drodze wiążących poleceń - obowiązków pracowniczych, jest zgodny z ogólną tendencją występującą w krajach Europy Zachodniej.

\section{Pracownicze podporządkowanie jako cecha konstrukcyjna stosunku pracy - uwagi de lege ferenda}

Dyskusja nad przyszłością pracowniczego podporządkowania jest elementem szerszej debaty nad modelem stosunku pracy oraz zakresem podmiotowym prawa pracy. $\mathrm{W}$ tym przedmiocie rysują się dwie zasadnicze koncepcje. Pierwsza $z$ nich, moim zadaniem trudna do zaakceptowania, idzie $\mathrm{w}$ kierunku odejścia od modelu stosunku pracy opartego na kryterium pracowniczego podporządkowania. Gorącym orędownikiem tej koncepcji jest A.M. Świątkowski, według którego de lege ferenda „przedmiotem stosunku pracy nie powinna być wyłącznie praca charakteryzująca się takimi cechami jak: osobiste jej wykonywanie, odpłatność, podporządkowanie oraz ryzyko pracodawcy, lecz każda praca świadczona za wynagrodzeniem przez osobę fizyczną w ramach jakiegokolwiek stosunku prawnego na rzecz podmiotu zatrudniającego" ${ }^{10}$.

Zdaniem tego autora, „uznanie za pracowników wszystkich osób fizycznych świadczących każdą pracę wykonywaną w zamian za wynagrodzenie wypłacane przez przedsiębiorcę, który w stosunkach społecznych regulowanych przepisami prawa pracy powinien zawsze występować w roli pracodawcy wobec wszystkich pracujących, bez względu na podstawę i prawne ramy zatrudnienia, [...] powinno być uznane przez polskich specjalistów prawa pracy za najważniejszy cel ewolucji stosunku pracy w drugim dziesięcioleciu XXI wieku"11.

${ }^{10}$ A.M. Świątkowski, Przedmiot stosunku pracy. Rozważania de lege lata $i$ de lege ferenda, [w:] Współczesne problemy prawa pracy i ubezpieczeń społecznych, XVIII Zjazd Katedr i Zakładów Prawa Pracy i Ubezpieczeń Społecznych, red. L. Florek, Ł. Pisarczyk, Warszawa 2011, s. 48. Podobnie idem, Przyszłość prawa pracy, [w:] Polskie prawo pracy w procesie przemian, red. A.M. Świątkowski, Warszawa-Kraków 1991, s. 19.

11 A.M. Świątkowski, Przedmiot stosunku pracy..., s. 59. Warto tu zauważyć, iż już w latach sześćdziesiątych XX w. S.M. Grzybowski proponował rozszerzenie prawa pracy na różne formy zatrudnienia niepracowniczego. Jego zdaniem, „ograniczenie prawa pracy do pracy najemnej jest brakiem świadczącym o niedokończeniu jego rozwoju" w: Wstęp 
Według A.M. Świątkowskiego, zaproponowana koncepcja - w dobie globalizacji, automatyzacji procesów pracy i postępu technologicznego - pozwoli na zagwarantowanie wszystkim zatrudnionym, bez względu na prawne formy i ramy świadczenia pracy, równego poziomu ochrony prawnej ${ }^{12}$. Konsekwencją realizacji wskazanych tu postulatów musiałoby być zastąpienie prawa pracy (labour law) szeroko rozumianym prawem zatrudnienia (the law of employment $)^{13}$. Zwolennikiem takiej wizji przyszłości prawa pracy, które swym zakresem regulacji obejmowałoby wszystkie formy pracy, gdzie głównym kryterium wyodrębnienia tak rozumianego prawa zatrudnienia "byłaby praca świadczona przez osoby utrzymujące się z pracy własnych rąk", wydaje się również np. J. Wratny ${ }^{14}$.

Zasadniczo nie jestem przeciwnikiem ekspansji prawa pracy na inne pozapracownicze formy świadczenia pracy za wynagrodzeniem. Uważam jednak, że należy pozostawić dotychczasową konstrukcję stosunku pracy opartą na kryterium pracy podporządkowanej. To właśnie ten model zatrudnienia musi gwarantować najszerszy (najpełniejszy) zakres ochrony, która winna rekompensować pracownikowi permanentny stan zależności (podporządkowania) względem pracodawcy. W pełni zgadzam się ze stanowiskiem B. Wagner, że przepisy wyznaczające konstrukcję stosunku pracy nastawione są przede wszystkim na ochronę pracownika najbardziej potrzebującego, a więc wykonawczego (najniżej lub nisko usytuowanego w hierarchii organizacyjnej zakładu pracy), najsłabszego ekonomicznie (uzyskującego dochody tylko z pracy najemnej) oraz socjalnie a do tego nieporadnego w dochodzeniu swych praw ${ }^{15}$. Natomiast wokół tak określonego modelu stosunku pracy, opartego na kryterium podporządkowania, możliwe jest budowanie innych regulacji ochronnych obejmujących swym zakresem (w mniejszym stopniu niż pracowników) pozostałych wykonawców pracy, działających w warunkach braku pracowniczego podporządkowania, ale zależnych ekonomicznie

do nauki prawa pracy, Kraków 1947. Także w latach dziewięćdziesiątych formułowane były $\mathrm{w}$ doktrynie prawa pracy postulaty stopniowego obejmowania paradygmatem stosunku pracy wszystkich wykonawców pracy, którzy nie mają rynkowej pozycji gospodarczo samodzielnego przedsiębiorcy. Por. np.: A. Chobot, A. Kijowski, Podstawowe problemy rozwoju prawa pracy, IX Zjazd Katedr Prawa Pracy, Torun 1990, s. 23 i nast.; A. Chobot, Nowe formy zatrudnienia, Kierunki rozwoju i nowelizacji, Warszawa 1997, s. 191 i nast.

12 A.M. Świątkowski, Przedmiot stosunku pracy..., s. 56.

${ }^{13}$ Terminologia ta znana jest w literaturze obcej. Np. R.W. Painter, A. Holms, Cases and materials on Employment Law, Oxford University Press, Oxford 2004.

${ }^{14} \mathrm{~J}$. Wratny, Przemiany stosunku pracy w III RP, [w:] Wspótczesne problemy prawa pracy i ubezpieczeń spotecznych..., s. 43-44.

${ }^{15}$ B. Wagner, O swobodzie umowy o prace raz jeszcze, [w:] Prawo pracy a wyzwania XXI wieku, Księga Jubileuszowa Prof. T. Zielińskiego, red. M. Matey-Tyrowicz, L. Nawacki, B. Wagner, Warszawa 2002, s. 378. 
od podmiotu zatrudniającego ${ }^{16}$. Takie ujęcie jest zgodne z powszechnym stanowiskiem doktryny prawa pracy, idącym $\mathrm{w}$ kierunku rozszerzania ochronnego ustawodawstwa pracy na osoby świadczące pracę na podstawie pozapracowniczych stosunków zatrudnienia ${ }^{17}$. Zmieniające się stosunki społeczno- gospodarcze, rozwój nowoczesnych technologii oraz nietypowych form zatrudnienia, za którymi idą postulaty w zakresie liberalizacji (uelastycznienia) prawa pracy, nie dają - moim zdaniem - podstaw do odejścia od modelu stosunku pracy opartego na paradygmacie pracy dobrowolnie podporządkowanej. Zgadzam się z W. Sanetra, iż wskazane tu zjawiska nie mogą „deformować pojęcia stosunku pracy, pozbawiając go koniecznej ścisłości i operatywności"18. Jego zdaniem stosunek pracy $\mathrm{w}$ dotychczasowym kształcie powinien odgrywać rolę „modelu oraz punktu odniesienia dla regulacji innych stosunków prawa pra-

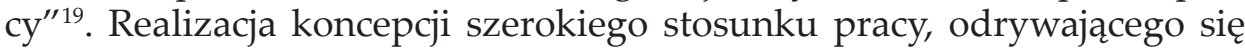
od kryterium pracowniczego podporządkowania i obejmującego zakresem podmiotowym wszystkich wykonawców świadczących pracę za wynagrodzeniem, prowadziłaby - według mnie - do swoistego rozmycia tradycyjnych konstrukcji i instytucji stosunku pracy oraz skutkowałaby istotną zmianą jego dotychczasowej jakości, co w konsekwencji mogłoby grozić utartą odrębności całego prawa pracy. Warto w tym miejscu przytoczyć słowa T. Zielińskiego, że zupełne wyłączenie kierownictwa pracodawcy, a z drugiej strony - podporządkowania pracownika w stosunkach pracy nie może wchodzić $w$ grę $e^{20}$. Według niego odejście od kryterium pracy podporządkowanej $\mathrm{w}$ ramach stosunku pracy podważałoby sens dalszego istnienia prawa pracy ${ }^{21}$. Zresztą wydaje się, że wypracowanie jednolitej koncepcji szerokiego stosunku pracy dla tak różnorodnych form stosunków społecznych, jakie wiążą się z wykonywaniem pracy zarobkowej, jest praktycznie niemożliwe ${ }^{22}$.

${ }_{16}$ Podobnie A. Musiała, Kilka uwag w zakresie zagadnienia stosunku pracy i jego przemian, [w:] Wspótczesne problemy prawa pracy i ubezpieczeń społecznych..., s. 241-242 i 248.

17 Zob. np.: M. Seweryński, Problemy rekodyfikacji prawa pracy, [w:] Prawo pracy a wyzwania XXI wieku..., s. 323-324; Z. Salwa, Przemiany prawa pracy poczatku stulecia a jego funkcja ochronna, [w:] Prawo pracy a wyzwania XXI wieku..., s. 303-304; Z. Hajn, Glosa do wyroku SN z 16 grudnia 1998 r., II UKN 394/98, OSP 2000, nr 12, poz. 177, s. 595; idem, Regulacja pozycji prawnej pracownika i pracodawcy a funkcje prawa pracy, „Praca i Zabezpieczenie Społeczne" 2000, nr 10, s. 5 i 11.

${ }^{18}$ W. Sanetra, Stosunek pracy i jego przemiany, [w:] Wspótczesne problemy prawa pracy i ubezpieczeń społecznych..., s. 32.

19 Ibidem, s. 33

20 T. Zieliński, Problem rekodyfikacji prawa pracy, „Państwo i Prawo” 1999, nr 7, s. 12-13.

${ }^{21}$ Idem, Umowy o zatrudnienie w aspekcie rekodyfikacji prawa pracy, [w:] Szczególne formy zatrudnienia, red. Z. Kubot, Wrocław 2000, s. 57.

${ }^{22}$ Podobnie M. Skąpski, Zagadnienia stosunku pracy między członkami rodziny, Warszawa 2000, s. 50. 
Uważam, że w przyszłości ustawodawca powinien pozostawić dotychczasowy model stosunku pracy odwołujący się do kryterium pracy podporządkowanej, które od dziesięcioleci stanowi cechę konstrukcyjną tego stosunku, odróżniającą go od innych prawnych stosunków zatrudnienia. To właśnie ten model, oparty na paradygmacie pracy dobrowolnie podporządkowanej, musi gwarantować najszerszy (najpełniejszy) zakres ochrony, która winna rekompensować pracownikowi permanentny stan zależności względem pracodawcy. W tym kierunku idzie projekt nowego Kodeksu pracy z kwietnia 2008 r. ${ }^{23}$, przygotowany przez Komisję Kodyfikacyjną Prawa Pracy ${ }^{24}$, której przewodniczył szanowny Jubilat, prof. zw. dr hab. Michał Seweryński. Zgodnie z art. 44 § 1 projektu, przez nawiązanie stosunku pracy pracownik zobowiązuje się do osobistego świadczenia pracy podporządkowanej określonego rodzaju, na rzecz pracodawcy i jego ryzyko, a pracodawca do zatrudniania pracownika za wynagrodzeniem. Z kolei jego art. 153 nakłada na pracownika powinność stosowania się do poleceń przełożonych, które dotyczą pracy, jeżeli nie są one sprzeczne z przepisami prawa lub umową o pracę. Zdecydowanie pozytywnie należy ocenić fakt, że w propozycji tej - uwzględniając dotychczasowe stanowisko doktryny prawa pracy - rezygnuje się ze zwrotu „pod kierownictwem pracodawcy", zastępując go terminem „podporządkowanie”. Zmiana ta niewątpliwie przyczyniłaby się do zamknięcia dyskusji nad niejasną relacją pomiędzy wskazanymi tu pojęciami, która obecnie toczy się w literaturze przedmiotu. Niestety podstawową wadą zaproponowanego unormowania jest brak precyzyjnego określenia treści pracowniczego podporządkowania jako cechy wyróżniającej stosunek pracy, co pozostawia - tak jak w obowiązującym stanie prawnym - daleko idącą swobodę w zakresie interpretacji najważniejszego kryterium decydującego o tożsamości tego stosunku zatrudnienia. Taka sytuacja - moim zdaniem - podważa sens jego wyodrębnienia. $\mathrm{W}$ pełni popieram stanowisko Z. Hajna, w myśl którego „możliwość efektywnego spełniania przez zasadę podporządkowania roli zasadniczego kryterium identyfikacji stosunku pracy zależy od posiadania przez nie dostatecznie sprecyzowanej treści" ${ }^{25}$.

Biorąc pod uwagę powyższe względy, de lege ferenda należy dookreślić w Kodeksie pracy kryterium pracowniczego podporządkowania. Nie chodzi jednak - w mojej opinii - o sformułowanie precyzyjnej jego definicji. Zależność pracownika od pracodawcy w ramach stosunku pracy ma charakter wieloaspektowy, może dotyczyć przedmiotu świadczenia pracy, miejsca, czasu, organizacji i porządku pracy. Elementy te występują

${ }^{23}$ Zob. www.mpips.gov.pl.

${ }^{24}$ Rozporządzenie Rady Ministrów z dnia 20 sierpnia 2002 r. w sprawie utworzenia Komisji Kodyfikacyjnej Prawa Pracy, DzU, 2002, nr 139, poz. 1167 z późn. zm.

${ }^{25}$ Z. Hajn, Glosa..., s. 593. 
$\mathrm{w}$ danym stosunku pracy z różną intensywnością, zależnie od zajmowanej przez pracownika pozycji (stanowiska), zakresu przydzielonych obowiązków i zadań czy też miejsca wykonywania pracy. Dlatego też ustawodawca powinien określić w Kodeksie pracy uniwersalny „rdzeń, składający się na każde podporządkowanie, którego zaistnienie będzie uzasadniać dopuszczalność zatrudnienia pracowniczego. Prawne doprecyzowanie minimalnego zakresu podporządkowania w każdym zatrudnieniu pracowniczym - moim zdaniem - musi spełniać dwa zasadnicze warunki. Po pierwsze, winno identyfikować stosunek pracy, pozwalając na jego w miarę precyzyjne odróżnienie od cywilnoprawnych form zatrudnienia. Po drugie zaś, musi ono uwzględniać autonomię i samodzielność pracowników oraz nie może stanowić przeszkody dla rozwoju elastycznych (nietypowych) form zatrudnienia pracowniczego. Moim zdaniem, jedynym aspektem zależności, który spełnia oba wymienione tu założenia i może tym samym stanowić minimalny zakres podporządkowania w każdym stosunku pracy, jest uprawnienie pracodawcy do konkretyzowania - w drodze wiążących poleceń - obowiązków pracowniczych. Chodzi tutaj o zagwarantowanie pracodawcy możliwości korzystania z tego uprawnienia, a konkretyzacja ta nie musi dotyczyć istoty wykonywanej pracy, ale może odnosić się jedynie do niektórych, często drugorzędnych, obowiązków pracownika związanych z techniczno-organizacyjną stroną świadczenia pracy. Dlatego też, odwołując się do istniejącej w art. $44 \S 1$ projektu nowego Kodeksu pracy z 2008 r. definicji stosunku pracy, opowiadam się za jej uzupełnieniem o sformułowanie, iż przez nawiązanie stosunku pracy pracownik zobowiązuje się do osobistego świadczenia pracy podporządkowanej określonego rodzaju, na rzecz pracodawcy i jego ryzyko, w ramach której pracodawca posiada uprawnienie do konkretyzacji - $\mathrm{w}$ drodze wiążących poleceń - jego obowiązków, a pracodawca do zatrudniania pracownika za wynagrodzeniem. Gdyby jednak ustawodawca zdecydował się na pozostawienie dotychczasowej formuły stosunku pracy, ujętej w art. $22 \S 1$ k.p., postulowałbym o jej modyfikację w następujący sposób: „Przez nawiązanie stosunku pracy pracownik zobowiązuje się do wykonywania osobiście pracy określonego rodzaju na rzecz pracodawcy i pod jego kierownictwem uprawniającym do konkretyzacji - w drodze wiążących poleceń - obowiązków pracowniczych, a pracodawca - do zatrudniania pracownika za wynagrodzeniem".

Tak doprecyzowany przez normodawcę "trzon” podporządkowania winien warunkować dopuszczalność wykorzystania stosunku pracy w każdym przypadku. Zaproponowana formuła podporządkowania, wbrew pozorom, umożliwia szerokie rozumienie stosunku pracy, mieszczą się w niej bowiem z powodzeniem zarówno pracownicy „profesjonal- 
ni" i wysokospecjalistyczni (samodzielni pracownicy nauki, sędziowie, radcy prawni bądź lekarze), jak i pracownicy świadczący pracę $\mathrm{w}$ nietypowych (elastycznych) formach zatrudnienia (pracownicy tymczasowi, telepracownicy czy osoby zatrudnione w zadaniowym czasie pracy). Ustawowe przyjęcie takiej interpretacji pracowniczego podporządkowania jest zgodne z tendencjami obowiązującymi w krajach Europy Zachodniej, gdzie dla scharakteryzowania pracy świadczonej na podstawie stosunku pracy odchodzi się od kryterium zależności ekonomicznej, zastępując je podporządkowaniem pracownika poleceniom pracodawcy. Przyjęcie formuły podporządkowania, odwołującej się do kryterium zależności ekonomicznej, skutkowałoby rozmyciem tej cechy stosunku pracy, a w konsekwencji zatarciem się i tak już mało wyraźnej granicy pomiędzy nim a umowami prawa cywilnego, do czego nie można dopuścić. Doszłoby wówczas do sytuacji, którą trudno zaakceptować, że z takiej samej ochrony, jaką gwarantuje stosunek pracy, korzystaliby pracownicy podlegający poleceniom pracodawcy oraz ci działający w warunkach całkowitej niezależności (autonomii) od podmiotu zatrudniającego. De lege ferenda kryterium zależności ekonomicznej może co najwyżej stanowić czynnik przesądzający o konieczności zastosowania wobec wykonawców świadczących pracę poza stosunkiem pracy pewnych ochronnych rozwiązań z zakresu prawa pracy.

\section{Bibliografia}

Chobot A., Nowe formy zatrudnienia. Kierunki rozwoju i nowelizacji, Warszawa 1997.

Chobot A., Kijowski A., Podstawowe problemy rozwoju prawa pracy, IX Zjazd Katedr Prawa Pracy, Toruń 1990.

Duraj T., Podporządkowanie pracowników zajmujących stanowiska kierownicze w organizacjach, Warszawa 2013.

Duraj T., Tradycyjne ujęcie pracowniczego podporzadkowania - wybrane problemy prawne, „Studia Prawno-Ekonomiczne" 2011, t. LXXXIII.

Fabre-Magnan M., Le contrat de travail défini par son objet, [w:] Le travail en perspectives, Paris 1998

Grzybowski S.M., Wstęp do nauki prawa pracy, Kraków 1947.

Hajn Z., Glosa do wyroku SN z 16 grudnia 1998 r., II UKN 394/98, OSP 2000, nr 12, poz. 177.

Hajn Z., Regulacja pozycji prawnej pracownika i pracodawcy a funkcje prawa pracy, „Praca i Zabezpieczenie Społeczne" 2000, nr 10.

Lewandowski H., Możliwość kontrolowania pracownika w ramach uprawnień kierowniczych pracodawcy - zagadnienia ogólne, [w:] Kontrola pracownika. Możliwości techniczne i dylematy prawne, red. Z. Góral, Warszawa 2010.

Lewandowski H., Uprawnienia kierownicze w umownym stosunku pracy, Warszawa 1977.

Musiała A., Kilka uwag w zakresie zagadnienia stosunku pracy i jego przemian, [w:] Wspótczesne problemy prawa pracy i ubezpieczeń społecznych, XVIII Zjazd Katedr i Zakładów Prawa Pracy i Ubezpieczeń Społecznych, red. L. Florek, Ł. Pisarczyk, Warszawa 2011. 
Painter R.W., Holms A., Cases and materials on Employment Law, Oxford University Press, Oxford 2004.

Salwa Z., Przemiany prawa pracy poczatku stulecia a jego funkcja ochronna, [w:] Prawo pracy a wyzwania XXI wieku. Księga Jubileuszowa Prof. T. Zielińskiego, red. M. Matey-Tyrowicz, L. Nawacki, B. Wagner, Warszawa 2002.

Sanetra W., Stosunek pracy i jego przemiany, [w:] Wspótczesne problemy prawa pracy i ubezpieczeń społecznych, XVIII Zjazd Katedr i Zakładów Prawa Pracy i Ubezpieczeń Społecznych, red. L. Florek, Ł. Pisarczyk, Warszawa 2011.

Seweryński M., Problemy rekodyfikacji prawa pracy, [w:] Prawo pracy a wyzwania XXI wieku. Ksiegga Jubileuszowa Prof. T. Zielińskiego, red. M. Matey-Tyrowicz, L. Nawacki, B. Wagner, Warszawa 2002.

Skąpski M., Zagadnienia stosunku pracy między członkami rodziny, Warszawa 2000.

Skibińska E., Prawo poszukujacych pracy do pobierania świadczeń, „Monitor Prawa Pracy” $2009, \mathrm{nr} 8$.

Supiot A., Zatrudnienie pracownicze i zatrudnienie niezależne, [w:] Referaty na VI Europejski Kongres Prawa Pracy i Zabezpieczenia Społecznego, Warszawa 1999.

Świątkowski A.M., Przedmiot stosunku pracy. Rozważania de lege lata $i$ de lege ferenda, [w:] Wspótczesne problemy prawa pracy i ubezpieczeń społecznych, XVIII Zjazd Katedr i Zakładów Prawa Pracy i Ubezpieczeń Społecznych, red. L. Florek, Ł. Pisarczyk, Warszawa 2011.

Świątkowski A.M., Przyszłość prawa pracy, [w:] Polskie prawo pracy w procesie przemian, red. A.M. Świątkowski, Warszawa-Kraków 1991.

Wagner B., O swobodzie umowy o prace raz jeszcze, [w:] Prawo pracy a wyzwania XXI wieku. Ksiega Jubileuszowa Prof. T. Zielińskiego, red. M. Matey-Tyrowicz, L. Nawacki, B. Wagner, Warszawa 2002.

Wratny J., Przemiany stosunku pracy w III RP, [w:] Wspótczesne problemy prawa pracy i ubezpieczeń społecznych, XVIII Zjazd Katedr i Zakładów Prawa Pracy i Ubezpieczeń Społecznych, red. L. Florek, Ł. Pisarczyk, Warszawa 2011.

Zarys systemu prawa pracy. Część ogólna prawa pracy, t. I, red. K.W. Baran, Warszawa 2010.

Zieliński T., Problem rekodyfikacji prawa pracy, „Państwo i Prawo” 1999, nr 7.

Zieliński T., Umowy o zatrudnienie w aspekcie rekodyfikacji prawa pracy, [w:] Szczególne formy zatrudnienia, red. Z. Kubot, Wrocław 2000.

\section{The Future of the Employee's Subordination as Structural Feature of the Employment Relationship}

\section{Summary}

The author of the foregoing study reflects on the future of the institution of the employee's subordination defined mainly as submission of the employee to the authority of the employer in the work process. Since the very beginning of the labour law employee's subordination has been described in the literature of the subject and judicial decisions as an inherent (necessary) constituent of the employment relationship. In spite of the ongoing technological development, and an increasing popularity of the modern varieties of work organisation and atypical forms of employment, which emphasize greater independence of the employee, the existing model of the employment relationship referring to the criterion of subordination should still be prevailing in the future. It should still con- 
stitute the basic and inherent structural feature which determines the existence of an employment relationship. The legislature de lege ferenda must, however, specify in the Labour Code, the minimum extent of the employee's subordination. According to the author, such extent in any relationship is defined by the employer's privilege to specify - by means of binding instructions - the employee's duties. Clarifying the criterion of the employee's subordination in the Labour Code in such way identifies on the one hand the employment relationship, allowing it to be distinguished from civil forms of employment, and on the other hand, takes into account the autonomy of employees without constituting an obstacle to the development of flexible forms of employment. 